\title{
Syndecan-1 expression has prognostic significance in head and neck carcinoma
}

\author{
A Anttonen'1, M Kajanti' ${ }^{1}$, P Heikkilä ${ }^{2}$, M Jalkanen³ and H Joensuu ${ }^{1}$ \\ Departments of ${ }^{1}$ Oncology and ${ }^{2}$ Pathology, Helsinki University Central Hospital, FIN-20521 Helsinki, Finland; ${ }^{3}$ Turku Center for Biotechnology, FIN-20521 \\ Turku, Finland
}

Summary The syndecans are a family of cell-surface heparan sulphate proteoglycans that regulate cell behaviour by binding extracellular matrix molecules such as growth factors. The syndecan family has four members, of which syndecan-1 is the most studied and best characterized. We have studied the prognostic significance of syndecan-1 expression in squamous cell carcinoma (SCC) of the head and neck treated with surgery and post-operative radiotherapy. Paraffin-embedded tissue samples taken from 175 patients with primary SCC, followed up from 2 to 15 years after surgery, were studied for expression of syndecan- 1 by immunohistochemistry. A low number $(\leq 50 \%$, the median value) of syndecan-1-positive tumour cells was associated with low histological grade of differentiation $(P<0.0001)$, a large primary tumour size (T1-2 vs T3-4, $P=0.02$ ), positive nodal status (N0 vs N1-3, $P=0.0006$ ), and high clinical stage (stage I or II vs III or IV, $P<0.0001)$. Low syndecan-1 expression was also associated with unfavourable overall survival in a univariate analysis $(P=0.001)$. In a multivariate survival analysis, the clinical stage and syndecan-1 expression were the only independent prognostic factors. We conclude that syndecan-1 is a novel prognostic factor in SCC of the head and neck treated with surgery and post-operative radiotherapy.

Keywords: proteoglycan; squamous cell carcinoma; head and neck cancer; prognosis; syndecan

Extracellular matrix (ECM) molecules and growth factors participate in regulation of cellular behaviour by binding to specific cellsurface receptors. Earlier studies have shown that reduced intercellular adhesion, disturbed differentiation and changes in the composition of the basement membrane influence the development of malignant tumours (Weinstein et al, 1976; Liotta et al, 1986). Heparan sulphate proteoglycans (HSPGs) are macromolecules which are present at the cell surface. They are involved in cell-cell adhesion and the interaction of cells with ECM (Ruoslahti, 1989). They are also thought to act as coreceptors for the heparin-binding growth factors (HBGFs), thus participating in regulation of cell behaviour (reviewed by Bernfield et al, 1992).

Syndecan-1 is a member of a family of cell-surface HSPGs, which consists of at least four members named syndecans 1 to 4 (Bernfield et al, 1992; Jalkanen et al, 1993). They all have homologous transmembrane and cytoplasmic domains, but their extracellular domains are different (Bernfield et al, 1992; Jalkanen et al, 1983). Syndecan-1 was originally found on the surface of normal murine mammary gland epithelial cells (Rapraeger and Bernfield, 1993), and to date it is the most studied member of the syndecan family. Syndecan-1 is suggested to act as a matrix receptor, because it binds to various ECM molecules via its heparan sulphate chains and contacts the cytoskeleton through its cytoplasmic domain (Elenius et al, 1990). Components of ECM to which syndecan-1 has been shown to bind include type I, III and V collagen (Koda et al, 1985), fibronectin (Saunders and Bernfield, 1988), thrombospondin (Sun et al, 1989), tenascin (Salmivirta et al, 1991), amphoterin

Received 10 December 1997

Revised 22 June 1998

Accepted 13 July 1998

Correspondence to: $\mathrm{H}$ Joensuu, Department of Oncology, Helsinki University Central Hospital, Haartmaninkatu 4, FIN-00290 Helsinki, Finland
(Salmivirta et al, 1992) and laminin (Salmivirta et al, 1994). Syndecan-1 also binds the basic fibroblast growth factor (bFGF) (Elenius et al, 1992).

During organogenesis and tissue formation, the expression of syndecan is strictly regulated and follows morphogenetic rather than histological boundaries and correlates with the reciprocal epithelial-mesenchymal interactions (Thesleff et al, 1988; Vainio et al, 1989). In a normal adult, syndecan-1 is mainly expressed in epithelial tissue, where the strongest expression is found in stratified epithelia at the cell-cell contacts in epidermal keratinocytes (Hayashi et al, 1987; Inki et al, 1991), which suggests that syndecan-1 is involved in intercellular adhesion of keratinocytes. In keratinocytes, syndecan-1 is localized at the cell surface, predominantly in the suprabasal cell layers, whereas the basal cell layer shows only weak expression. Small amounts of syndecan-1 have been shown to be expressed in fibroblasts (Elenius et al, 1992) and endothelial cells (Kojima et al, 1992). The role of syndecan in wound healing has also been studied, revealing increased syndecan expression in proliferating and migrating epithelial cells of the epidermis and in hair follicles and some expression on the vascular endothelial cells of granulation tissue proliferation and differentiation, suggesting that syndecan is involved in growth factor regulation (Elenius et al, 1991; Bernfield et al, 1992).

Expression of syndecan-1 has been found to be decreased in cellular transformation models. The DNA-binding protein encoded by the Wilms' tumour-suppressor gene wt 1 has recently been found to function as a transcriptional activator of syndecan-1 expression (Cook et al, 1997). When syndecan-1 was transfected into S115 mouse mammary tumour cells, the re-expression of syndecan-1 restored the epithelial morphology of the S115 cells (Leppä et al, 1992). Mouse skin exposed to irradiation shows loss of syndecan-1 expression, and expression switches from the granular layer to the basal and lower spinous layers after 2 weeks of 
daily irradiation (Liu et al, 1997). Syndecan-1 is found by immunohistochemistry in keratinizing cells of the horn pearls in well-differentiated carcinomas, but in poorly differentiated carcinomas syndecan-1 expression may be lost (Inki et al, 1992). In premalignant lesions of stratified epithelia, syndecan-1 is lost from the basally located, atypical cell layers (Inki et al, 1991). Loss of syndecan-1 from transformed cells could be one mechanism by which tumour cells lose their attachment to each other and to the ECM and become non-responsive to the signals coming from their microenvironment (Inki et al, 1994a).

There are few data available on the prognostic value of syndecan expression in human cancer. The two pilot studies involving 29 and 89 invasive SCC head and neck carcinomas have suggested that reduced syndecan-1 expression is associated with poor survival in SCC of the head and neck (Inki et al, 1994b; Pulkkinen et al, 1997), but to the best of our knowledge syndecan1 expression has not been shown to have independent prognostic value in any type of human cancer, including cancer of the head and neck. In the present study, we investigated syndecan-1 expression with 2 syndecan- 1 antibodies against human syndecan- 1 in a homogeneously treated series of 175 patients with squamous cell head and neck carcinoma with a minimum follow-up of 2 years and found syndecan- 1 expression to have prognostic value that was independent of clinical stage and histological grade.

\section{MATERIALS AND METHODS}

\section{Patients}

We collected the clinical data on 265 patients with histologically diagnosed SCC of the head and neck who were treated with surgery and post-operative irradiation in Helsinki University Central Hospital during the period from 1975 to 1990. Ninety patients were excluded because of insufficient data or non-available paraffin-embedded tissue. The remaining 175 patients had carcinoma of the larynx $(n=51)$, the tongue $(n=50)$, the floor of the mouth $(n=22)$, the lower gum $(n=22)$, the tonsil $(n=15)$ or the hypopharynx $(n=15)$. The data collected for each patient included age, sex, primary tumour site, tumour size, cervical nodal status, overall TNM stage, histological grade, treatment and cause of death. Of the 175 patients, $21(12 \%)$ had stage 1, 29 (17\%) stage II, $81(46 \%)$ stage III and $44(25 \%)$ stage IV cancer, but none had distant metastases at the time of the diagnosis. The study group comprised $126(72 \%)$ male and $49(28 \%)$ female patients. The mean age at the time of the diagnosis was 60 (range 19-86). All patients were treated with radical surgery and post-operative splitcourse radiotherapy to a total dose of $66 \mathrm{~Gy}$ and a daily fraction size of 2.0-2.2 Gy given in five fractions a week for 9 weeks, with a 3 -week rest in the middle of the treatment. The minimum followup time of the patients after the diagnosis was 2 years (range 2-15 years). The overall 2-year survival rate was $63 \%$ and the 5-year survival rate $43 \%$. Staging was done according to the UICC classification (1978, Table 1).

\section{Histology}

The analysis of syndecan-1 expression was made from formalinfixed and paraffin-embedded tumour samples using immunohistochemistry. Histology of the tumours was reviewed by one pathologist $(\mathrm{PH})$, who graded the tumours according to the WHO classification (Shamugaratnam and Sobin, 1978), except for 12
Table 1 Site and stage distribution of 175 SCCs of the head and neck

\begin{tabular}{|c|c|c|c|}
\hline Primary tumour & Stage & $n$ & (\%) \\
\hline \multicolumn{4}{|l|}{ Larynx } \\
\hline & 2 & 6 & (12) \\
\hline & 3 & 32 & (63) \\
\hline & 4 & 13 & (25) \\
\hline \multicolumn{4}{|l|}{ Tongue } \\
\hline & 1 & 20 & (40) \\
\hline & 2 & 11 & (22) \\
\hline & 3 & 16 & (32) \\
\hline & 4 & 3 & (6) \\
\hline \multicolumn{4}{|l|}{ Oral cavitya } \\
\hline & 2 & 9 & (20) \\
\hline & 3 & 20 & (46) \\
\hline & 4 & 15 & (34) \\
\hline \multicolumn{4}{|l|}{ Tonsil } \\
\hline & 1 & 1 & (7) \\
\hline & 2 & 2 & (13) \\
\hline & 3 & 5 & (33) \\
\hline & 4 & 7 & (47) \\
\hline \multicolumn{4}{|l|}{ Hypopharynx } \\
\hline & 2 & 1 & (7) \\
\hline & 3 & 8 & (53) \\
\hline & 4 & 6 & (40) \\
\hline
\end{tabular}

aSCCs of the lower gum or the floor of the mouth.

Table 2 Association between syndecan-1 expression and seven clinicopathological factors in SCC of the head and neck (staining with B-B4, $n=167)^{\text {a }}$

\begin{tabular}{|c|c|c|c|}
\hline \multirow[t]{2}{*}{ Factor } & \multicolumn{2}{|c|}{$\begin{array}{l}\text { Percentage of syndecan- } \\
\text { 1-positive tumour cells }\end{array}$} & \multirow[b]{2}{*}{$P$} \\
\hline & $\begin{array}{l}\leq \mathbf{5 0 \%} \\
n(\%)\end{array}$ & $\begin{array}{l}>50 \% \\
n(\%)\end{array}$ & \\
\hline \multicolumn{4}{|c|}{ Histological grade ${ }^{b}$} \\
\hline Grade I & $15(30)$ & $35(70)$ & \\
\hline Grade II & $30(43)$ & $40(57)$ & \\
\hline Grade III & $33(94)$ & $2(6)$ & $<0.0001$ \\
\hline \multicolumn{4}{|l|}{ Stage } \\
\hline $1-2$ & $13(27)$ & $35(73)$ & \\
\hline $3-4$ & $75(63)$ & $44(37)$ & $<0.0001$ \\
\hline \multicolumn{4}{|l|}{ Nodal status } \\
\hline NO & $38(41)$ & $55(59)$ & \\
\hline N1-3 & $50(68)$ & $24(32)$ & 0.0006 \\
\hline \multicolumn{4}{|l|}{ Tumour size } \\
\hline T1-2 & $37(44)$ & $47(56)$ & \\
\hline T3-4 & $51(61)$ & $32(39)$ & 0.02 \\
\hline \multicolumn{4}{|c|}{ Karnofsky's performance status } \\
\hline $60-80$ & $49(52)$ & $46(48)$ & \\
\hline $90-100$ & $39(54)$ & $33(46)$ & 0.74 \\
\hline \multicolumn{4}{|c|}{$\begin{array}{l}\text { Width of the surgical resection } \\
\text { marginc }^{c}\end{array}$} \\
\hline$<0.5 \mathrm{~cm}$ & $43(52)$ & $40(48)$ & \\
\hline $0.5-2.0 \mathrm{~cm}$ & $43(53)$ & $38(47)$ & 0.87 \\
\hline \multicolumn{4}{|l|}{ Gender } \\
\hline Male & $63(53)$ & $57(47)$ & \\
\hline Female & $25(53)$ & $22(47)$ & 0.94 \\
\hline
\end{tabular}

aEight slides were excluded because of technical reasons. ${ }^{b} T w e l v e$ carcinomas were of a non-keratinizing type and were not graded. ${ }^{\mathrm{T}}$ Three cases had incomplete data. 
samples which were classified as non-keratinizing carcinomas and were not graded.

\section{Immunohistochemistry}

Syndecan-1 was studied from paraffin-embedded samples by immunohistochemistry using both a mouse monoclonal antibody against human syndecan-1 (B-B4, Serotec, Oxford, UK) and a specific rat monoclonal antibody 104-9 (produced by Dr M Jalkanen's group) against human syndecan-1- derived peptide (amino acid residues 88-110). All 175 samples were successfully stained with the 104-9 antibody and 167 slides with the B-B4 antibody (8 slides were excluded because of technical reasons).
Tissue samples were cut into $5-\mu \mathrm{m}$ sections on Vectabond slides. The slides were kept at $+37^{\circ} \mathrm{C}$ for up to $24 \mathrm{~h}$ and then deparaffinized and dehydrated. The avidin-biotin immunoperoxidase method was used. Pretreated slides were incubated with $2 \%$ normal goat serum in $1 \%$ bovine serum albumin (BSA; Sigma, St. Louis, MO, USA) for $20 \mathrm{~min}$ at room temperature (RT), followed by B-B4 or 104-9 antibody in $0.3 \%$ BSA overnight at RT at a concentration of 1:200 (B-B4) or 1:100 (104-9). After washing twice with phosphate-buffered saline (PBS), the slides were incubated with Vectastain biotinylated anti-mouse IgG (Vector laboratories, Burlingame, CA, USA) in the case of B-B4 or biotinylated anti-rat IgG in the case of 104-9 (Vector laboratories) in $0.3 \%$ BSA for $30 \mathrm{~min}$ at RT. The slides were then washed twice with

\section{A}

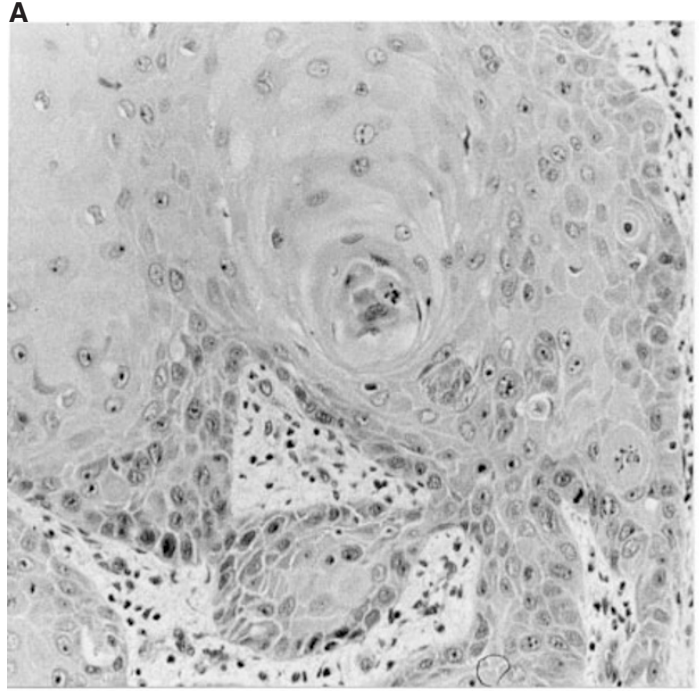

\section{C}

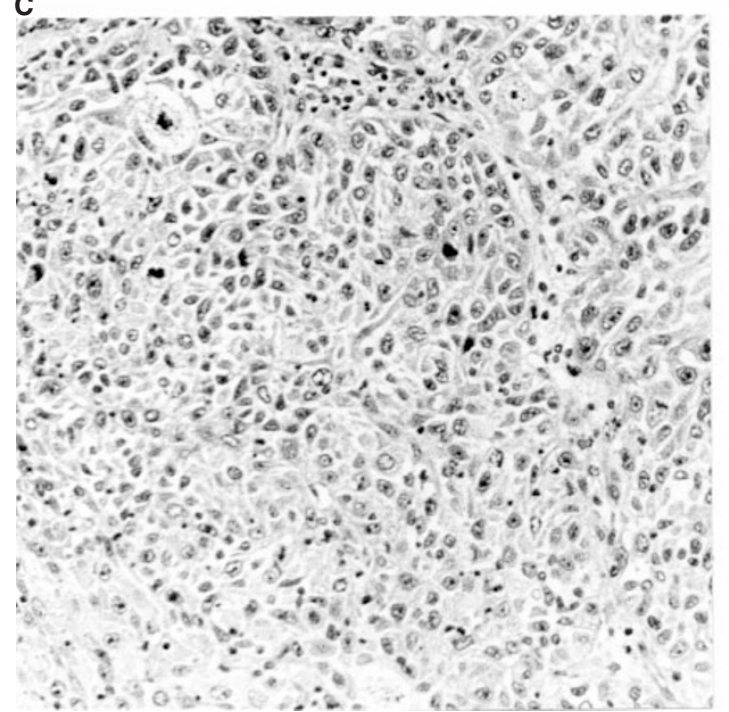

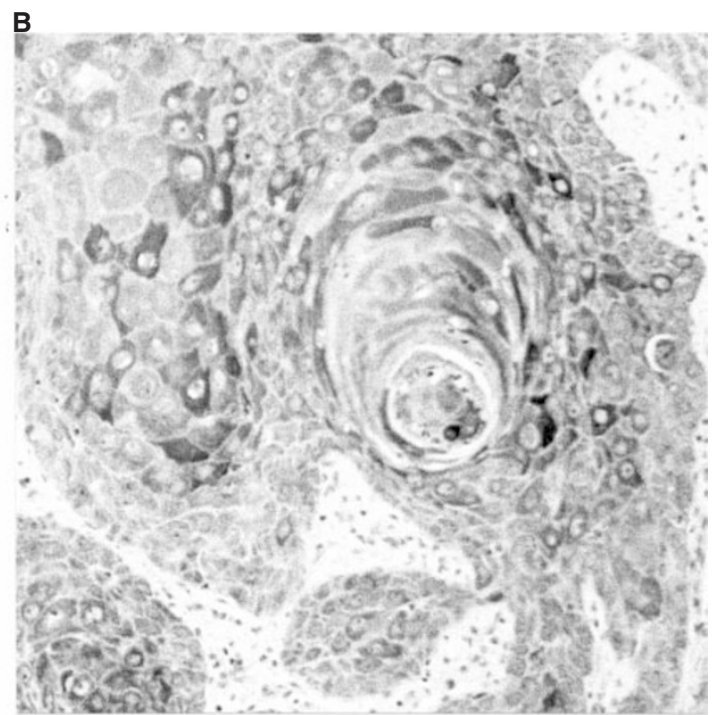

D

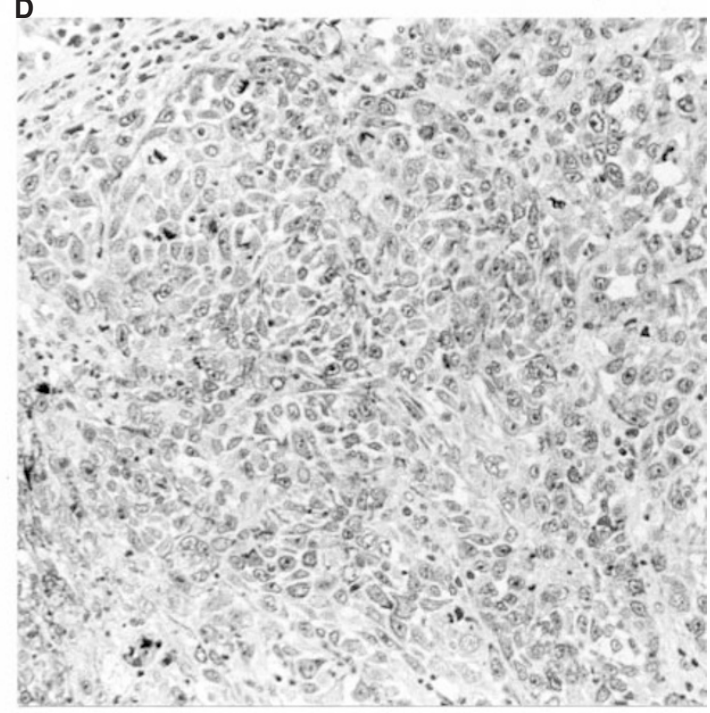

Figure 1 Haematoxylin and eosin-stained sections ( $\mathbf{A}$ and $\mathbf{C}$ ) from SCCs of the head and neck, and same sections stained for syndecan-1 by immunohistochemistry (stained with 104-9 antibody (B and D). Well-differentiated SCC of the tongue (A), in which 100\% of the tumour cells show at least some positivity in staining for syndecan-1, although the staining intensity varies markedly (B). Poorly differentiated SCC of the larynx (C), where none of the tumour cells are positive for syndecan- 1 (D). All magnifications $\times 360$ 
PBS, followed by avidin DH-biotinylated horseradish peroxidase mixture according to the manufacturer's instructions (Vector Laboratories) for $1 \mathrm{~h}$ at RT. After incubation, the slides were washed again twice with PBS, and for colour reaction, the slides were incubated with $0.02 \% 3$-amino-9-ethylcarbazole (in $\mathrm{N}, \mathrm{N}$ dimethylformamide) and $0.1 \%$ hydrogen peroxidase in $0.05 \mathrm{M}$ acetate buffer, $\mathrm{pH} 5.0$ for $20 \mathrm{~min}$ at RT, counterstained with haematoxylin and mounted. Histologically normal skin was used as a positive control and stainings without the primary antibody were used as negative controls.

Immunoreactivity of syndecan-1 was assessed visually. First, the percentage of syndecan-1-positive tumour cells was calculated from at least five representative fields per slide (Olympus Optical Company, Tokyo, Japan, $\times 10$ objective, diameter $2.6 \mathrm{~mm}$, area $5.31 \mathrm{~mm}^{2}$ ). Then, the mean percentage of positive cells per field was calculated. One representative slide was assessed per case. Forty slides in both staining groups were reassessed by two of the investigators (AA and $\mathrm{PH}$ ) in order to study the inter-observer variability. The inter-observer variability turned out to be low between the two observers. The kappa coefficients were 0.62 (B-B4) and 0.65 (104-9), which shows a good agreement between the observers. Assessment of syndecan expression was done blindly without any knowledge of the clinical or survival data.

\section{Statistical analysis}

Statistical analyses were done by using a BMDP computer program (BMDP, Statistical software, University of California Press, LA, USA). Cumulative survival was estimated with the product-limit method. The Mantel-Cox's test was used for comparison of survival between groups. Frequency tables were analysed with the Chi-square test. The relative importance of prognostic factors was analysed with Cox's proportional hazard regression analysis (BMDP 2L). All $P$-values are 2-tailed.

\section{RESULTS}

The median percentage of syndecan-1-expressing cancer cells was $50 \%$ when staining was performed with the B-B4 antibody. Only in two cases $(1 \%)$ were all cancer cells positive for syndecan-1, and only ten $(6 \%)$ tumours showed entirely negative staining. The results were similar independent of site, and 58\%, 49\%, and $43 \%$ of larynx, tongue and oral cavity carcinomas, respectively, had $\leq 50 \%$ of cells that stained positively for syndecan- 1 .

The percentage of tumour cells positive for syndecan-1 (B-B4) was $>50 \%$ more often in well- or moderately well-differentiated cancers than in the poorly differentiated ones $(P<0.0001$, Table 2$)$. A strong $(>50 \%)$ syndecan-1 expression was also associated with a low stage $(P<0.0001)$, lack of lymph node metastases $(P=0.0006)$ and a small primary tumour size $(P=0.02)$. No association between syndecan-1 expression and preoperative Karnofsky's performance status, gender or the width of the surgical resection margin was found (Table 2).

When the series was stained for syndecan-1 with the 104-9 antibody instead of B-B4, in $50(29 \%)$ cases the percentage of syndecan-1-positive tumour cells was $80 \%$ or less, in $21(12 \%)$ cases from $81 \%$ to $90 \%$ of the cells were positive, in $14(8 \%)$ cases almost all cancer cells (about 95\%) were positive and in $90(51 \%)$ practically all cancer cells expressed syndecan-1. As, in this staining, in the majority of cases almost all cancer cells were positive for syndecan-1, we chose $80 \%$ as the cut-off value because it approximately defined the lowest quartile. Only three $(2 \%)$
Table 3 Association between syndecan-1 expression and seven clinicopathological factors in SCC of the head and neck (staining with 104-9, $n=175)$

\begin{tabular}{|c|c|c|c|}
\hline \multirow[t]{2}{*}{ Factor } & \multicolumn{2}{|c|}{$\begin{array}{l}\text { Percentage of syndecan-1- } \\
\text { positive tumour cells }\end{array}$} & \multirow[b]{2}{*}{$P$} \\
\hline & $\begin{array}{l}\leq 80 \% \\
n(\%)\end{array}$ & $\begin{array}{l}>80 \% \\
n(\%)\end{array}$ & \\
\hline \multicolumn{4}{|c|}{ Histological grade ${ }^{a}$} \\
\hline Grade I & $7(13)$ & $46(87)$ & \\
\hline Grade II & $16(21)$ & $59(79)$ & \\
\hline Grade III & $21(60)$ & $14(40)$ & $<0.0001$ \\
\hline \multicolumn{4}{|l|}{ Gender } \\
\hline Male & $42(33)$ & $84(67)$ & \\
\hline Female & $8(16)$ & $41(84)$ & 0.03 \\
\hline \multicolumn{4}{|c|}{$\begin{array}{l}\text { Width of the surgical resection } \\
\text { margin }^{\text {b }}\end{array}$} \\
\hline$<0.5 \mathrm{~cm}$ & $31(35)$ & $57(65)$ & \\
\hline $0.5-2.0 \mathrm{~cm}$ & $19(23)$ & $65(77)$ & 0.07 \\
\hline \multicolumn{4}{|c|}{ Karnofsky's performance status } \\
\hline $60-80$ & $24(24)$ & $75(76)$ & \\
\hline $90-100$ & $26(34)$ & $50(66)$ & 0.15 \\
\hline \multicolumn{4}{|l|}{ Nodal status } \\
\hline NO & $25(26)$ & $72(74)$ & \\
\hline $\mathrm{N} 1-3$ & $25(32)$ & $53(68)$ & 0.36 \\
\hline \multicolumn{4}{|l|}{ Stage } \\
\hline $1-2$ & $13(26)$ & $37(74)$ & \\
\hline $3-4$ & $37(30)$ & $88(70)$ & 0.63 \\
\hline \multicolumn{4}{|l|}{ Tumour size } \\
\hline $\mathrm{T} 1-2$ & $24(28)$ & $62(72)$ & \\
\hline T3-4 & $26(29)$ & $63(71)$ & 0.85 \\
\hline
\end{tabular}

aTwelve carcinomas were of a non-keratinizing type and were not graded. bThree cases had incomplete data.

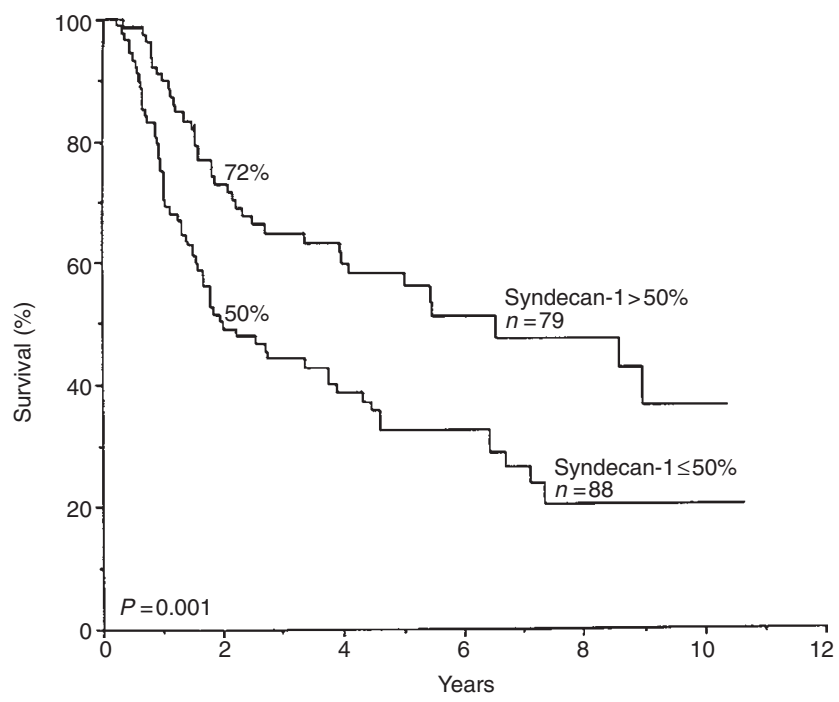

Figure 2 Survival by syndecan-1 expression in 167 patients with SCC of the head and neck (stained with B-B4)

tumours showed entirely negative staining. Examples of staining are shown in Figure 1.

When the data obtained by 104-9 were used in the analyses, low syndecan-1 expression $(\leq 80 \%)$ was again strongly associated with 
Table 4 Prognostic value of nine factors in SCC of the head and neck

\begin{tabular}{|c|c|c|c|}
\hline Factor & $n$ & $\begin{array}{c}\text { Two-year } \\
\text { survival (\%) }\end{array}$ & $P$-value \\
\hline \multicolumn{4}{|l|}{ Clinical stage } \\
\hline St 1-2 & 48 & 86 & \\
\hline St 3-4 & 119 & 51 & 0.0002 \\
\hline \multicolumn{4}{|l|}{ Tumour size } \\
\hline $\mathrm{T} 1-2$ & 84 & 76 & \\
\hline T3-4 & 83 & 47 & 0.0002 \\
\hline \multicolumn{4}{|l|}{ Nodal status } \\
\hline No & 93 & 72 & \\
\hline N1-3 & 74 & 47 & 0.0009 \\
\hline \multicolumn{4}{|c|}{ Syndecan-1 (stained with B-B4) } \\
\hline$\leq 50 \%$ & 88 & 50 & \\
\hline$>50 \%$ & 79 & 72 & 0.001 \\
\hline \multicolumn{4}{|c|}{ Karnofsky's performance status } \\
\hline $60-80$ & 95 & 57 & \\
\hline $90-100$ & 72 & 67 & 0.006 \\
\hline \multicolumn{4}{|c|}{ Syndecan-1 (stained with 104-9) } \\
\hline$\leq 80 \%$ & 50 & 47 & \\
\hline$>80 \%$ & 125 & 66 & 0.02 \\
\hline \multicolumn{4}{|c|}{$\begin{array}{l}\text { Width of the surgical resection } \\
\text { margina }^{\text {a }}\end{array}$} \\
\hline$<0.5 \mathrm{~cm}$ & 83 & 54 & \\
\hline $0.5-2.0 \mathrm{~cm}$ & 81 & 67 & 0.02 \\
\hline \multicolumn{4}{|c|}{ Histological grade } \\
\hline Grade I & 50 & 71 & \\
\hline Grade II & 70 & 57 & \\
\hline Grade III & 35 & 53 & 0.05 \\
\hline \multicolumn{4}{|l|}{ Gender } \\
\hline Male & 120 & 61 & \\
\hline Female & 47 & 61 & 0.50 \\
\hline
\end{tabular}

aThree cases had incomplete data. ${ }^{\text {b}}$ Twelve carcinomas were of a nonkeratinizing type and were not graded.

a low histological grade $(P<0.0001$, Table 3$)$ and also with the male gender $(P=0.03)$. However, no association between syndecan-1 expression and the stage $(P=0.63)$, the nodal status $(P=0.36)$ or the primary tumour size $(P=0.85)$ was found (Table 3$)$.

\section{Association of syndecan-1 expression with survival}

Strong ( $>50 \%)$ syndecan-1 expression was associated with favourable overall survival $(P=0.001, \mathrm{~B}-\mathrm{B} 4$ staining, Figure 2$)$. When the percentage of syndecan-1-positive tumour cells was over $50 \%$, the 2 -year survival rate was $72 \%$ and the 5 -year survival rate $56 \%$, whereas, if the percentage of syndecan-1-positive cells was less than $50 \%$, the corresponding rates were only $50 \%$ and $32 \%$ respectively. A similar result was found when the SCCs of the larynx (the largest single subgroup) were analysed separately: a high $(>50 \%)$ syndecan-1 expression was associated with favourable overall survival $(P=0.04$, Figure 3$)$. Among patients with laryngeal cancer, the 2-year survival rate was $81 \%$ and the 5 -year survival rate $59 \%$ if more than $50 \%$ of cancer cells stained positively for syndecan-1, but only $48 \%$ and $33 \%$, respectively, if $\leq 50 \%$ of cells were positive. When the 104-9 antibody was used, a strong $(>80 \%)$ syndecan-1 expression was again associated with favourable overall survival $(P=0.02$, Table 4$)$. If the percentage of syndecan-1-positive tumour cells was over $80 \%$, the 2-year survival rate was $66 \%$ and, if $80 \%$ or less, only $47 \%$ (Figure 4 ).

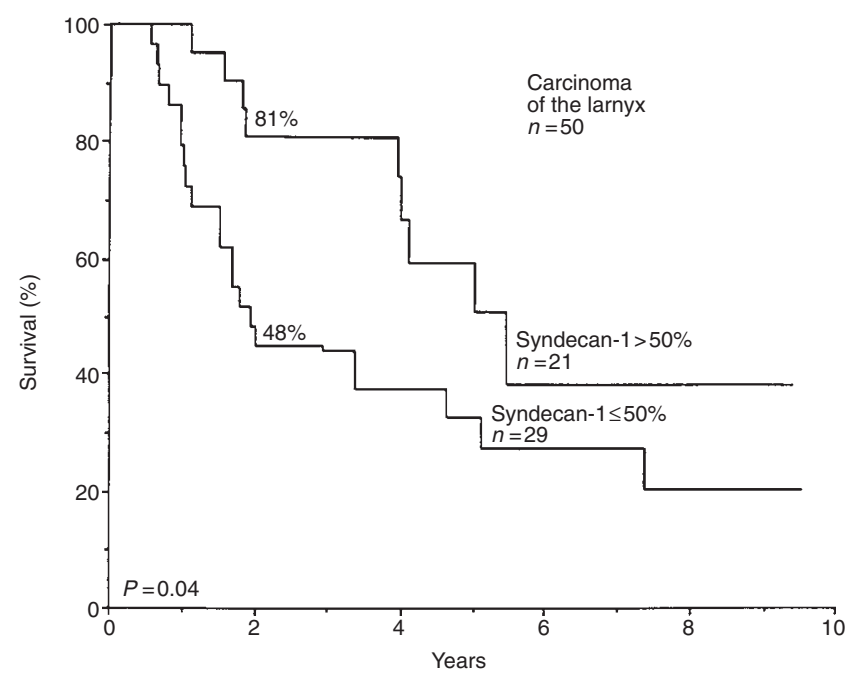

Figure 3 Survival by syndecan-1 expression in 50 patients with SCC of the larynx (stained with B-B4)

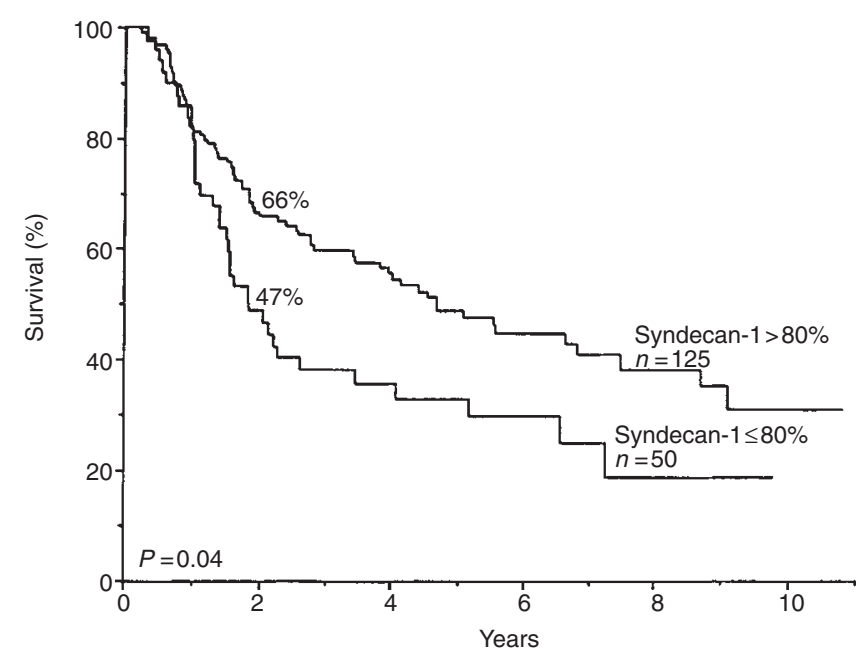

Figure 4 Survival by syndecan-1 expression in 175 patients with SCC of the head and neck (stained with 104-9)

Several factors other than syndecan-1 expression were significantly associated with survival in the series in a univariate survival analysis (Table 4$)$. These included the clinical stage $(P=0.0002)$, nodal status $(P=0.0009)$, tumour size $(P=0.0002)$, Karnofsky's performance status $(P=0.006)$, the width of the surgical margin $(P=0.02)$ and histological grade $(P=0.05)$. In a multivariate analysis of the entire series, the clinical stage [relative risk (RR) 2.1, 95\% confidence interval (CI) 1.2-3.8], expression of syndecan-1 (B-B4) (RR 1.9, 95\% CI 1.2-3.1) and possibly the width of the surgical margin (RR 1.5, 95\% CI 1.0-2.4) had independent prognostic value influencing overall survival (Table 5). When we entered only the SCCs of the larynx into the model, strong syndecan-1 expression and the width of the surgical margin turned out to be the only independent factors influencing survival.

The results remained essentially similar when staining with 104-9 was used instead of B-B4 staining in a multivariate 
Table 5 Results of Cox's stepwise proportional hazard model in SCC of the head and neck

\begin{tabular}{|c|c|c|c|c|c|c|}
\hline Factor & $\beta$ & s.e. & $\beta /$ s.e. $^{a}$ & $P$ & $\begin{array}{c}\mathbf{R R}^{\mathbf{b}} \\
(95 \%<1)\end{array}$ & $\begin{array}{l}\text { Step of } \\
\text { removal }\end{array}$ \\
\hline \multicolumn{7}{|l|}{ Clinical stage } \\
\hline (3-4 vs $1-2)$ & 0.75 & 0.30 & 2.46 & $<0.001$ & $2.1(1.2-3.8)$ & 1 \\
\hline \multicolumn{7}{|c|}{$\begin{array}{l}\text { Syndecan-1 expression } \\
\text { (B-B4) }\end{array}$} \\
\hline$(\leq 50 \%$ vs $>50 \%)$ & 0.65 & 0.24 & 2.72 & 0.016 & $1.9(1.2-3.1)$ & 2 \\
\hline Width of the surgica & & & & & & \\
\hline $\begin{array}{l}(<0.5 \mathrm{~cm} \text { vs } \\
0.5-2.0 \mathrm{~cm})\end{array}$ & 0.43 & 0.23 & 1.91 & 0.055 & $1.5(1.0-2.4)$ & 3 \\
\hline $\begin{array}{l}\text { Histological grade } \\
\text { (III vs II vs I) }\end{array}$ & & & & & $\mathrm{NS}^{c}$ & \\
\hline $\begin{array}{l}\text { Karnofsky's status } \\
\quad(\leq 80 \text { vs }>80)\end{array}$ & & & & & NS & \\
\hline $\begin{array}{l}\text { Nodal status } \\
\text { (N1-3 vs N0) }\end{array}$ & & & & & NS & \\
\hline
\end{tabular}

$\mathrm{a} \beta$ is the estimated regression coefficient of the hazard function, s.e. is the standard error and $\beta /$ s.e. describes their significance. ${ }^{b} \mathrm{RR}$ is the relative risk, $95 \%$ confidence limits are given for the relative risk of death. ${ }^{\mathrm{N} S}$ not significant.

analysis. The clinical stage (RR 2.6, 95\% CI 1.5-4.4) and expression of syndecan-1 (RR 1.7, 95\% CI 1.1-2.6) turned out to be the only independent prognostic factors.

\section{DISCUSSION}

In the present study, we investigated the association of syndecan-1 expression with prognosis in SCC of the head and neck. The series consisted of 175 patients diagnosed with SCC of the head and neck and treated in a uniform fashion, and syndecan-1 expression was assessed using both a specific mouse anti-human antibody BB4 and a rat monoclonal antibody 104-9 against human syndecan1 by immunohistochemistry. Syndecan-1 expression (B-B4) in more than $50 \%$ of cancer cells was associated with favourable outcome in both a univariate and a multivariate survival analysis, and it was also associated with a small primary tumour size, lack of nodal metastases and, in particular, high histological grade of differentiation. The findings were similar in the entire series and in the largest subgroup studied (laryngeal cancer). Moreover, essentially similar results were obtained with the 104-9 antibody. The minor difference between the results obtained with these two antibodies can be explained by their recognition epitopes, which for B-B4 is the intact cell surface form of syndecan-1, but in the case of the 104-9 antibody, is the core protein only.

Earlier, we found a low syndecan- 1 expression to be associated with poor survival, in a much smaller series consisting of only 29 patients, using a polyclonal affinity-purified rabbit antibody (antiP117) that works only in unfixed tissue (Inki et al, 1994b). Although all these staining data with three different anti-syndecan-1 antibodies support the association between low syndecan-1 expression and poor survival in squamous cell head and neck cancer, it has not been established how the loss of syndecan-1 contributes to poor outcome. Normal tissue and well-differentiated SCCs show stronger syndecan-1 expression than do undifferentiated carcinomas. According to one hypothesis, syndecan-1 expression is diminished during malignant transformation and, therefore, soluble growth factors might reach more easily growth factor receptors located on the plasma membrane, resulting in more sustained stimulation of the cell growth. Cells that have lost syndecan-1 may also be more loosely bound to the extracellular matrix, which may contribute to metastasis formation.

The role of histological grading as a prognostic factor is not settled in head and neck cancer. In some studies, histological grading has been found to have prognostic value (Pera et al, 1986; Wiernik et al, 1991), while some others disagree (Bundgaard et al, 1992). In the present study, a low histological grade of differentiation was only marginally associated with unfavourable overall survival $(P=0.05)$. Although histological grading is generally considered to be a prognostic factor in head and neck cancer, it is subjective and, therefore, often difficult to reproduce (Bundgaard et al, 1992). Syndecan-1 expression may be a valuable adjunct to histological grading, because we found a high degree of uniformity in assessment of syndecan-1 expression between the two classifiers, and syndecan-1 expression appears to be associated at least as strongly with prognosis as is histological grading. Reliable methods for assessment of the biological aggressiveness of head and neck cancer are becoming more and more important because there is now evidence that the novel aggressive treatments, such as chemotherapy given concomitantly or alternating with radiotherapy (El-Sayed et al, 1996; Benasso et al, 1997), or the new radiotherapy fractionation schemes (Horiot et al, 1992), may result in improved survival.

In conclusion, decreased expression of syndecan-1 is associated with low histological grade of differentiation and poor outcome in SCC of the head and neck treated with surgery and post-operative radiotherapy. In the present series, syndecan-1 expression was the only independent prognostic factor together with the clinical stage. Hence, syndecan-1 expression appears to be a novel prognostic factor in head and neck cancer. Its role as a predictive and prognostic factor in other types of human cancer now need to be explored. 


\section{ACKNOWLEDGEMENTS}

We thank associate professor Seppo Sarna for advice on statistical analysis, Dr Veli-Matti Wasenius, Mrs Päivi Laurila, Mrs Päivi Tainola, Ms Päivi Heino, Ms Kati Konola and Mrs Elina Roimaa for technical advice and docent Pekka Virkkunen for help in preparing the figures. This study was supported by the Cancer Society of Finland and the Academy of Finland

\section{REFERENCES}

Benasso M, Bonelli L, Numico G, Corvo R, Sanguineti G, Rosso R, Vitale V and Merlano M (1997) Treatment with cisplatin and fluorouracil alternating with radiation favourably affects prognosis of inoperable squamous cell carcinoma of the head and neck: results of a multivariate analysis on 273 patients. Ann Oncol 8: 773-779

Bernfield M, Kokenyesi R, Kato M, Hinkes MT, Spring J, Gallo RL and Lose E (1992) Biology of syndecans. Annu Rev Cell Biol 8: 365-393

Bundgaard T, Sørensen FB, Gaihede M, Søgaard H and Overgaard J (1992) Stereometric, histopathologic, flow cytometric and clinical parameters in the prognostic evaluation of 74 patients with intraoral squamous cell carcinomas. Cancer 70: 1-13

Cook DM, Hinkes MT, Bernfield M and Rausher FL III (1997) Transcriptional activation of the syndecan-1 promoter by the Wilms' tumor protein WT1. Oncogene 13: 1789-1799

Elenius K, Salmivirta M, Inki P, Mali M and Jalkanen M (1990) Binding of human syndecan to extracellular matrix proteins. J Biol Chem 29: 17837-17843

Elenius K, Vainio S, Laato M, Salmivirta M, Thesleff I and Jalkanen M (1991) Induced expression of syndecan in healing wounds. J Cell Biol 114: 585-595

Elenius K, Määttä A, Salmivirta M and Jalkanen M (1992) Growth factors induce 3 T3 cells to express bFGF-binding syndecan. J Biol Chem 25: 6435-6441

El-Sayed S and Nelson N (1996) Adjuvant and adjunctive chemotherapy in the management of squamous cell carcinoma of the head and neck region. A metaanalysis of prospective and randomized trials. J Clin Oncol 14: 838-847

Hayashi K, Hayashi M, Jalkanen M, Firestone JH, Trelstad RL and Bernfield M (1987) Immunocytochemistry of cell surface heparan sulfate proteoglycan in mouse tissue. A light and electron microscopic study. J Histochem Cytochem 35: $1079-1088$

Horiot JC, Le Fur R, N'guyen T, Chenal C, Schraub S, Alfonsi S, Gardani G, Van Den Bogaert W, Danzak S, Bolla M, Van Glabbeke M and De Pauw M (1992) Hyperfractionation versus conventional fractionation in oropharyngeal carcinoma: final analysis of a randomized trial of the EORTC cooperative group of radiotherapy. Radiother Oncol 25: 231-241

Inki P, Stenbäck F, Talve L and Jalkanen M (1991) Immunohistochemical localization of syndecan in mouse skin tumors induced by UV irradiation. Am J Pathol 139: 1333-1340

Inki P, Kujari H and Jalkanen M (1992) Syndecan in carcinomas produced from transformed epithelial cells in nude mice. Lab Invest 66: 314-323

Inki P, Larjava H, Haapasalmi K, Miettinen H, Grenman R and Jalkanen M (1994a) Expression of syndecan-1 is induced by differentiation and suppressed by malignant transformation of human keratinocytes. Eur J Cell Biol 63: 43-51

Inki P, Joensuu H, Grenman R, Klemi P and Jalkanen M (1994b) Association between syndecan- 1 expression and clinical outcome in squamous cell carcinoma of the head and neck. Br J Cancer 70: 319-323
Jalkanen M, Elenius K and Rapraeger A (1993) Syndecan: regulator of cell morphology and growth factor action at the cell-matrix interface. Trends Glycosci Glycotechn 5: 107-120

Koda J, Rapraeger A and Bernfield M (1985) Heparan sulfate proteoglycans from mouse mammary epithelial cells. Cell surface proteoglycan as a receptor for interstitial collagens. J Biol Chem 260: 8157-8162

Kojima T, Scworak NW and Rosenberg RD (1992) Molecular cloning and expression of two distinct cDNAs encoding heparan sulfate proteoglycan core proteins from a rat endothelial cell line. J Biol Chem 267: 4870-4877

Leppä S, Mali M, Miettinen H and Jalkanen M (1992) Syndecan expression regulates cell morphology and growth of mouse mammary epithelial tumor cells. Proc Natl Acad Sci USA 89: 932-936

Liotta LA, Rao CN and Wewer UM (1986) Biochemical interactions of tumor cells with the basement membrane. Annu Rev Biochem 55: 1037-1051

Liu K, Kasper M, Bierhaus A, Langer S, Peterson I, Muller M and Trott KR (1997) Differential expression of CD44 and CD44v10 proteins and syndecan in normal and irradiated mouse epidermis. Histochem Clee Biol 107: 159-167

Pera E, Moreno A and Galino L (1986) Prognostic factors in laryngeal carcinoma. Cancer 58: 928-934

Pulkkinen JO, Penttinen M, Jalkanen M, Klemi P and Grenman R (1997) Syndecan1: a new prognostic marker in laryngeal cancer. Acta Otolaryngol (Stockh) 117: 312-315

Rapraeger A and Bernfield M (1983) Heparan sulfate proteoglycans from mouse mammary epithelial cells. A putative membrane proteoglycan associates quantitatively with lipid vesicles. J Biol Chem 258: 3632-3636

Ruoslahti E (1989) Proteoglycans in cell regulation. J Biol Chem 264: 13369-13372

Salmivirta M, Elenius K, Vainio S, Hofer U, Chiquet-Erismann R, Thesleff I and Jalkanen M (1991) Syndecan from embryonic tooth mesenchyme binds tenascin. J Biol Chem 266: 7733-7739

Salmivirta M, Rauvala H, Elenius K and Jalkanen M (1992) Neurite growthpromoting protein (amphoterin, p30) binds syndecan. Exp Cell Res 200 444-451

Salmivirta M, Mali M, Heino J, Hermonen J and Jalkanen M (1994) A novel laminin-binding form of syndecan-1 (cell surface proteoglycan) produced by syndecan-1 cDNA-transfected NIH-3T3 cells. Exp Cell Res 215: 180-188

Saunders S and Bernfield M (1988) Cell surface proteoglycan binds mouse mammary epithelial cells to fibronectin and behaves as a receptor on interstitial matrix. J Cell Biol 106: 423-430

Shanmugaratnam K and Sobin LH (eds) (1978) Histological Typing of Upper Respiratory Tract Tumours, pp. 14-33. WHO: Geneva

Sun X, Mosher DF and Rapraeger A (1989) Heparan sulfate-mediated binding of epithelial cell surface proteoglycan to thrombospondin. J Biol Chem 264: 2885-2889

Thesleff I, Jalkanen M, Vainio S and Bernfield M (1988) Cell surface proteoglycan expression correlates with epithelial-mesenchymal interaction during tooth morphogenesis. Dev Biol 129: 565-572

Vainio S, Lehtonen E, Jalkanen M, Bernfield M and Saxen L (1989) Epithelial-mesenchymal interactions regulate the stage-specific expression of a cell surface proteoglycan, in the developing kidney. Dev Biol 134: 382-391

Weinstein RS, Merk FB and Alroy J (1976) The structure and function of intercellular junctions in cancer. Adv Cancer Res 23: 25-33

Wiernik G, Millard PR and Haybittle JL (1991) The predictive value of histological classification into degrees of differentiation of squamous cell carcinoma of the larynx and hypopharynx compared with the survival of patients. Histopathology 19: 411-417 